\title{
Effects of Diets Containing Asyastasia gangetica and Brachiaria decumbens on Intake, Digestibility and Growth Performance of Growing Rabbits
}

\author{
Mohammad Mijanur Rahman ${ }^{1,2 *}$, Siti Nafisah Binti Ismail ${ }^{1}$, Khairiyah Mat $^{1,2}$, \\ Takahiro Gondo ${ }^{3}$, Maryana Mohamad Nor ${ }^{1,2}$ and Ryo Akashi ${ }^{3}$ \\ ${ }^{1}$ Faculty of Agro Based Industry, Universiti Malaysia Kelantan, Jeli Campus, 17600 Jeli, Kelantan, Malaysia \\ ${ }^{2}$ Institute of Food Security and Sustainable Agriculture, Universiti Malaysia Kelantan, Jeli Campus, 17600 \\ Jeli, Kelantan, Malaysia \\ ${ }^{3}$ Faculty of Agriculture, University of Miyazaki, Miyazaki Shi 889-2192, Miyazaki, Japan
}

\begin{abstract}
The beneficial effects of feeding rabbits with forages have been recommended. However, limited study has been made on feeding values of locally available forages in rabbits. Therefore, an experiment was conducted to evaluate the effect of Asyastasia gangetica and Brachiaria decunbens on intake, digestibility, and growth performance of rabbits. Twelve rabbits were distributed into three diets: (i) 100\% commercial pellet as control (T1), (ii) 50\% pellet plus Asyastasia gangetica ad libitum (T2), and (iii) 50\% pellet plus Brachiaria decumbens ad libitum (T3). Daily feed intake, nutrient digestibility, weekly body weight, and feed conversion ratio (FCR) were measured. Intakes of total dry matter (DM) $(121.2-134.3 \mathrm{~g} / \mathrm{d})$ and organic matter (OM)

ARTICLE INFO

Article history:

Received: 27 April 2020

Accepted: 17 August 2020

Published: 27 November 2020

DOI: https://doi.org/10.47836/pjtas.43.4.14

E-mail addresses:

mijanur.r@umk.edu.my (Mohammad Mijanur Rahman) nafisah.f16b0245@siswa.umk.edu.my (Siti Nafisah Binti Ismail) khairiyah@umk.edu.my (Khairiyah Mat)

gondo@cc.miyazaki-u.ac.jp (Takahiro Gondo)

maryana.mn@umk.edu.my (Maryana Mohamad Nor)

rakashi@cc.miyazaki-u.ac.jp (Ryo Akashi)

*Corresponding author

$(115.1-132.5 \mathrm{~g} / \mathrm{d})$ were similar $(p>0.05)$ for all the groups. The crude protein (CP) intake of rabbits fed with $\mathrm{T} 1(10.1 \mathrm{~g} / \mathrm{d})$ and T3 (9.6 g/d) diets was similar $(p>0.05)$, but lower $(p<0.05)$ than T2 $(14.1 \mathrm{~g} / \mathrm{d})$ diet. Ether extract intake of rabbits fed with T2 $(2.9 \mathrm{~g} / \mathrm{d})$ and T3 $(3.9 \mathrm{~g} / \mathrm{d})$ diets was similar $(p>0.05)$, but lower $(p<0.05)$ than T1 $(5.1 \mathrm{~g} / \mathrm{d})$ diet. Neutral detergent fibre (NDF) intake was higher $(p<0.05)$ for rabbits fed with T3 (55.8 $\mathrm{g} / \mathrm{d})$ diet followed by T2 (41.7 g/d) and T1
\end{abstract}


$(31.7 \mathrm{~g} / \mathrm{d})$ diets. There were no differences $(p>0.05)$ on the digestibilities of DM, OM, and $\mathrm{CP}$ among treatments. Total weight gain and daily weight gain were higher $(p<0.05)$ for rabbits fed with $\mathrm{T} 1$ (568 and $11.0 \mathrm{~g})$ and T2 (468 and $9.0 \mathrm{~g}$ ) diets than T3 (155 and $3.3 \mathrm{~g})$ diet, respectively. The lowest FCR was obtained with T1 (12.3) and T2 (13.9) diets, whereas the highest was obtained with T3 (30.3) diet. In conclusion, diet containing Asyastasia gangetica showed more benefits in terms of CP and NDF intakes, weight gain and FCR than the diet containing Brachiaria decumbens. A combination of concentrate and Asyastasia gangetica is recommended as a partial replacement for concentrate in rabbit production.

Keywords: Asyastasia gangetica, Brachiaria decumbens, digestibility, growth performance, intake, rabbit

\section{INTRODUCTION}

Rabbit farming is gaining popularity in smallholder farmers as an alternative source of animal protein. Rabbit is considered as one of the suitable high quality animal proteins in developing countries (Owoleke et al., 2016). Smallholder farmers get faster benefits from rabbit farming compared to other farming systems (e.g., cattle farming), because rabbits require low investment, show short generation interval and have the ability to consume forage grasses. For profitable rabbit production, feed is considered as one of the most important inputs. When rabbits receive feeds containing required amount of energy and protein, they can provide better quality meat as a healthy diet for human consumption. Production of high quality meat at lower prices is achievable when locally available forage plants are included in rabbit's diet.

Safwat et al. (2014) stated that many forages could be used in ration formulation by replacing the costly protein sources. It depends on the forages' chemical composition, viability, palatability, and anti-nutritional factors. Rabbits fed leaves of browse plants and concentrate showed better performance than those fed tropical grasses with concentrate as reported by Amata and Okorodudu (2016). Adigun et al. (2014) also reported that $66 \%$ of wheat offal could be replaced with Asyastasia gangetica leaf meal as a fibre source in the diet of rabbit.

Asyastasia gangetica could be used as a substitute for legumes as reported by Adetula (2004). It is considered as suitable protein and mineral sources for goats (Khalil, 2016). Because of its ability to fastgrow naturally, resulting in low production cost, and high nutritive value, $A$. gangetica is utilised as forage for ruminants in SouthEast Asia; it is either grazed or cut for stall feeding (Gopal et al., 2013). Besides having these attributes, this plant can tolerate shade well. It grows prolifically in Malaysia especially at shaded and plantation areas (Chuku et al., 2018). Most of the farmers also feed their livestock with forages like Brachiaria decumbens. In Malaysia, $B$. decumbens is being used as a main plant in farming pasture and it is the most favored species for grazing ruminants (Low, 2015). 
However, level of concentrate offered to rabbits should not be below 50\% (50g) when fed with bracharia hay as recommended by Iyeghe-Erakpotobor et al. (2006), and poor utilisation of bracharia hay in their study was observed especially when offered low concentrate level.

However, there is little information about the effect of these locally available forage grasses on rabbit performance. It is important to know about the nutrient status of above mentioned forages as it can support the production and growth of rabbits. Therefore, this study was conducted to compare the feeding effect of two local tropical forage grasses (Brachiaria decumbens and Asyastasia gangetica) with supplementation of concentrate on intake, nutrient digestibility, growth performance, and feed conversion ratio of weaned rabbits.

\section{MATERIALS AND METHODS}

\section{Study Site and Experimental Design}

An experiment with rabbits was carried out in rabbit house located at Agro Techno Park, Universiti Malaysia Kelantan (UMK), Jeli campus, Kelantan. All animal handling and procedures were approved by the UMK Animal Care and Use Ethics Committee (UMK/FIAT/ACUE/UG1/2018). The average daily temperature and monthly rainfall were $28^{\circ} \mathrm{C}$ and $260 \mathrm{~mm}$ during the experimental period (July - October 2019).

The experiment was conducted for 69 days (10 days as an adaptation period, 52 days as a growth trial and 7 days as a collection period) using twelve unsexed weaned mixed breed rabbits, about 2 months of age, which were obtained from local supplier. Before data collection, rabbits with an initial average body weight (BW) of $1080.8 \pm 275.4 \mathrm{~g}$ were adapted to the new enviroment for 10 days, when only commercial pelleted compound feed were offered them on ad libitum basis (140 g/ head/d). During adaptation period, the average daily pellet intake was $116.7 \pm 11.4$ $\mathrm{g} / \mathrm{head}$, which was about $11.0 \%$ of initial their BW. Based on these data, all rabbits with an average BW of $1175.3 \pm 287.8 \mathrm{~g}$ were divided into three dietary groups consisting of 4 rabbits of each: (i) commercial pelleted compound feed on ad libitum (11.0\% of their BW) basis which was served as control (T1), (ii) half of the control (5.5\% of their BW) plus Asyastasia gangetica on ad libitum (75 g dry matter/head/d) basis (T2), and (iii) half of the control $(5.5 \%$ of their BW) plus Brachiaria decumbens on ad libitum (83 g dry matter/head/d) basis (T3). Throughut the experimental period, the quantities of offered pellet (for T1), Asyastasia gangetica (for T2) and Brachiaria decumbens (for T3) were adjusted weekly to ensure at least $20 \%$ refusals. The quantities of offered pellet for $\mathrm{T} 2$ and T3 treatments were determined for individual rabbit on the basis of their BW, and adjusted weekly to account for BW changes. The pellet and grasses were offered in separate feeders. Water was supplied ad libitum in automatic pipe drinkers.

Both types of grass were harvested at pre-flowering stage daily in the morning from the experimental field of Agro Techno Park, UMK, and fed to rabbits as fresh basis. The commercial pelleted compound feed 
prepared by feed manufacturing company (Perniagaan Hasbin Jaya, Pulau Pinang, Malaysia) was purchased from a local supplier,. The feeds were offered to rabbits twice in the morning (8:00 am) and again in the afternoon $(4: 00 \mathrm{pm})$.

Approximate ME from daily offered pellet and grasses for T1, T2, and T3 diets were 2490.4, 2650.7, and $2266.3 \mathrm{kcal} / \mathrm{kg}$ DM, respectively. Similarly, approximate CP from daily offered pellet and grasses for $\mathrm{T} 1, \mathrm{~T} 2$, and $\mathrm{T} 3$ diets were 7.5, 11.8, and $7.8 \%$, respectively. The $\mathrm{ME}$ and $\mathrm{CP}$ values in rabbit's diet should be $2025 \mathrm{kcal} /$ $\mathrm{kg} \mathrm{DM}$ and $16.0 \%$, respectively, to meet the requirements of a growing rabbit, according to National Research Council (NRC) (1977). It seems that the quantities of energy in the diets were more than required, but the $\mathrm{CP}$ contents in the diets were low. It was hypothesized that rabbits could take the rest of the CP from daily offered ad libitum pellet or grasses.

The ingredients used in the diets and their chemical compositions are shown in Table 1. Daily feed offered and refusals were recorded to estimate feed intake, and their samples were taken once a week for determining dry weight. Before feeding, rabbits were weighed at the beginning of the experiment, at 1-week interval and at the end of the experiment. Average daily gain and feed conversion ratio (FCR) were calculated to see the difference between the treatments on rabbit's performance as described by Biobaku et al. (2003). The FCR was calculated using dry matter (DM) intake by dividing the body weight (BW) gain. During the collection period, samples of offered feeds, refusals and faeces were collected and stored in a freezer. At the end of collection period, the collected faeces samples from each rabbit were thawed and mixed together to get a representative sample.

\section{Chemical Analysis}

Samples of feeds and faeces were analysed to determine the DM, crude protein (CP), ether extract (EE), and ash contents according to Association of Official Analytical Chemists (AOAC) (2000). Neutral detergent fibre (NDF) of feeds was determined following the method of Van Soest et al. (1991).

\section{Statistical Analysis}

All data were analysed through one-way ANOVA using SPSS software. They were compared between treatments using Duncan's multiple range test (DMRT) at $p<0.05$.

\section{RESULTS AND DISCUSSION}

\section{Proximate Components}

Asyastasia gangetica and Brachiaria decumbens contained 15.5 and 20.9\% dry matter (DM), 85.7 and $92.2 \%$ organic matter (OM), 15.9 and $8.1 \%$ crude protein (CP), 1.4 and $2.8 \%$ ether extract (EE), 45.9 and $63.1 \%$ neutral detergent fibre (NDF), as well as 14.3 and $7.8 \%$ ash, respectively. The commercial pelleted compound feed contained $85.1 \% \mathrm{DM}, 98.6 \% \mathrm{OM}, 7.5 \% \mathrm{CP}$, $3.8 \%$ EE, $23.6 \%$ NDF, and $1.4 \%$ ash (Table 1). The DM content of the commercial pellet 
was higher than those of the forages. The $\mathrm{CP}$ content of the commercial pellet was similar with the value of $B$. decumbens but not with $A$. gengetica which had a higher value (15.9\%). Asyastasia gangetica also showed higher ash contents than the value of $B$. decumbens. In contrast, the $B$. decumbens contained comparatively higher DM, OM, EE, and NDF contents than the respective values of $A$. gangetica (Table 1). The CP content in $A$. gangetica in this study was lower than the findings of Adigun et al. (2014), who reported that the leaf meal from $A$. gangetica contained $19.3 \% \mathrm{CP}$. This variation may have resulted due to the use of different aged plants, because the nutrient contents in plants can be varied by plant maturity (Suhaimi et al., 2017). Besides, the differences in climate, rainfall and temperature of studied area are considered as factors that contribute in variation of $\mathrm{CP}$ content in plants.
Asyastasia gangetica contained 15.9\% $\mathrm{CP}$ in this study, making it suitable to replace conventional protein sources in rabbit's diet. Owoleke et al. (2016) reported that CP needed by rabbit was about $16-18 \%$, but $15-16 \%$ was also recommended for growing rabbit. In another study, Cheeke (1987) suggested that adult rabbits required about $12 \%$ of CP, $14 \%$ of crude fibre, and $2 \%$ of EE daily. This means that $A$. gangetica contains lower EE (1.4\%) than the daily EE requirment of rabbits.

Suhaimi et al. (2017) reported that the CP content of $B$. decumbens was about 9-20\%; and this value declined as the plant aged. Thus, the low CP content of $B$. decumbens found in this study (Table 1) may have resulted due to the usage of aged plants. Similarly, the NDF content in $B$. decumbens in this study was lower ( 63.0 vs. $69.2 \%$ ) than the findings of Silva et al. (2016) respectively, which can

Table 1

Chemical composition (\%) of the feed ingredients

\begin{tabular}{llll}
\hline Nutrients & $\begin{array}{l}\text { Commercial } \\
\text { pellet }\end{array}$ & $\begin{array}{l}\text { Asystasia } \\
\text { gangetica }\end{array}$ & $\begin{array}{l}\text { Brachiaria } \\
\text { decumbens }\end{array}$ \\
\hline Dry matter & 85.1 & 15.5 & 20.9 \\
Organic matter & 98.6 & 85.7 & 92.2 \\
Crude protein & 7.5 & 15.9 & 8.1 \\
Ether extract & 3.8 & 1.4 & 2.8 \\
Neutral detergent fibre & 23.6 & 45.9 & 63.1 \\
Ash & 1.4 & 14.3 & 7.8 \\
Metabolisable energy & 2490.4 & 2800.6 & 2076.9 \\
$(\mathrm{kcal} / \mathrm{kg} \text { dry matter })^{\beta}$ & & & \\
\hline
\end{tabular}

Note. ${ }^{\beta}$ Data obtained from the secondary data (Biobaku et al., 2003; Sobayo et al., 2012; Suhaimi et al., 2017) 
also be explained due to the differences in plant maturity and location of studied areas. Besides other nutrients, NDF is also important in rabbit's diet; the NDF value of commercial pellet was much lower than those of the forages, which is a positive trait as excess NDF content $(>60 \%)$ can affect negatively on total DM intake in animals (Mertens, 1997). Nevertheless, rabbit has the ability to utilise the NDF efficiently due to the presence of microorganisms in their caecum.

The ash content of commercial pellet was lower than those of the forages. The ash content in $A$. gangetica was much higher than the $B$. decumbens, which can provide more minerals to the animal compared to other feed ingredients used in this study. When formulating rabbit's diet, the percentage of all nutrients must be taken into account to fulfill the nutrient requirments of rabbit.

\section{Dry Matter and Nutrients Intakes}

The feeding effect of $A$. gangetica and $B$. decumbens on daily intakes of DM and other nutritional components by rabbits is given in Table 2. Rabbits fed with T3 diet showed higher daily forage DM intake than those fed with T2 diet, whereas there was no difference on daily pellet DM intake between rabbits fed with $\mathrm{T} 2$ and $\mathrm{T} 3$ diets as their diet of commercial pellet was the same. However, replacement of half of commercial pellet by offering of test forages on ad libitum basis did not affect $(p>0.05)$ the daily total DM and OM intakes by rabbits, which suggests that test forages have potential to be used as feed in rabbit's diet. This result is in agreement with Amata and Okorodudu (2016), who stated that 50:50 mixtures of concentrate (maize) and forage (Centrocema pubescens) led to maximum performance in rabbit. The optimum total DM and OM intakes in this study were achieved when rabbits fed with test forages ad libitum in combination with $50 \%$ concentrate. A certain ratio of these forages to concentrate may give optimum rabbit performance that could lead to reduced feed cost.

Rabbits fed with T2 diet showed significantly $(p<0.05)$ higher $(14.1 \mathrm{~g} / \mathrm{d})$ CP intake followed by rabbits fed with T1 $(10.1 \mathrm{~g} / \mathrm{d})$ and T3 $(9.6 \mathrm{~g} / \mathrm{d})$ diets, whereas no influence of CP intake was observed between rabbits fed $\mathrm{T} 1$ and $\mathrm{T} 3$ diets. This may be explained due to the lower CP contents in both commercial pellet and $B$. decumbens compared to A. gangetica (Table 1). Thus, B. decumbens can be considered as an unsuitable protein source in rabbit's diet as supply of plenty of T3 diet had no influence on rabbit's $\mathrm{CP}$ intake.

Khalil (2016) reported that $A$. gangetica was a suitable complementary protein and mineral source for goat. Therefore, it is also a good complementary feed for rabbit because of high CP value. Nowadays, chicken and beef meat are being replaced with rabbit meat in human diet because of its high quality protein; nevertheless rabbits require adequate amount of protein in their diet for maintenance and growth.

Rabbits fed with $\mathrm{T} 1$ diet showed higher $(5.1 \mathrm{~g} / \mathrm{d})$ EE intake followed by T3 (3.9 g/d) and T2 (2.9 g/d) diets, which 
Table 2

Feed intake and digestibility of nutritional components by rabbits fed commercial pellet with or without Asystasia gangetica and Brachiaria decumbens

\begin{tabular}{lllll}
\hline Parameter & \multicolumn{3}{c}{ Treatment } & p-value \\
\cline { 2 - 3 } & T1 & T2 & T3 \\
\hline Intake (g/d) & & & & \\
Grass DM & $0.0^{\mathrm{c}} \pm 0.0$ & $62.0^{\mathrm{b}} \pm 4.0$ & $68.9^{\mathrm{a}} \pm 4.0$ & 0.000 \\
Pellet DM & $134.3^{\mathrm{a}} \pm 27.0$ & $53.8^{\mathrm{b}} \pm 7.1$ & $52.3^{\mathrm{b}} \pm 3.1$ & 0.000 \\
Total DM & $134.3 \pm 27.0$ & $115.8 \pm 9.4$ & $121.2 \pm 4.9$ & 0.360 \\
Total OM & $132.5 \pm 26.6$ & $107.5 \pm 9.1$ & $115.1 \pm 4.7$ & 0.144 \\
Total CP & $10.1^{\mathrm{b}} \pm 2.0$ & $14.1^{\mathrm{a}} \pm 0.9$ & $9.6^{\mathrm{b}} \pm 0.4$ & 0.020 \\
Total EE & $5.1^{\mathrm{a}} \pm 1.0$ & $2.9^{\mathrm{b}} \pm 0.3$ & $3.9^{\mathrm{b}} \pm 0.2$ & 0.003 \\
Total NDF & $31.7^{\mathrm{c}} \pm 6.4$ & $41.7^{\mathrm{b}} \pm 2.7$ & $55.8^{\mathrm{a}} \pm 2.6$ & 0.000 \\
Digestibility $(\%)$ & & & & \\
DM & $52.5 \pm 6.2$ & $58.0 \pm 1.9$ & $49.1 \pm 6.0$ & 0.092 \\
OM & $63.0 \pm 4.4$ & $63.4 \pm 1.7$ & $56.6 \pm 5.2$ & 0.081 \\
CP & $71.6 \pm 3.4$ & $70.9 \pm 1.7$ & $68.5 \pm 3.3$ & 0.328 \\
\hline
\end{tabular}

Note. ${ }^{\text {abc }}$ means with different superscripts in a row differ significantly $(p<0.05)$. $\mathrm{T} 1=$ control diet containing $100 \%$ commercial pellet; T2 = half of the control diet plus Asystasia gangetica on ad libitum basis; T3 = half of the control diet plus Brachiaria decumbens on ad libitum basis. DM = dry matter; OM = organic matter; $\mathrm{CP}=$ crude protein; $\mathrm{EE}=$ ether extract; $\mathrm{NDF}=$ neutral detergent fibre

could be reflected due to the higher EE content in commercial pellet than other treatments containing test forages. There was no significant $(p>0.05)$ difference on EE intake between the rabbits fed with T2 and T3 diets. Although total DM intake was reduced with increasing levels of EE in rabbit's diet as reported by Choi and Palmquist (1996), there was no influence on total DM intake among the treatments in the present study. This could be due to the presence of optimum level of EE in the experimental diets, which might be lower than the maximum level acceptable for use in rabbit's diet preventing adverse effect on their DM intake.
Total NDF intake increased $(p<0.05)$ as commercial pellet was replaced by test forages. Rabbits fed T3 diet showed higher $(55.8 \mathrm{~g} / \mathrm{d})$ NDF intake followed by T2 $(41.7 \mathrm{~g} / \mathrm{d})$ and T1 $(31.7 \mathrm{~g} / \mathrm{d})$ diets. This was attributed due to the use of different feed ingredients in the diets that contained different NDF contents (Table 1). Assis et al. (2019) reported that the NDF intake by animals could be increased when the energy density of the diet was low.

The DM and nutrient digestibility by the rabbits fed on different treatments are shown in Table 2. Similar to total DM and OM intakes, no influence $(p>0.05)$ of experimental diets was observed on the 
digestibility of nutritional fractions. The DM digestibility for T3 diet containing $B$. decumbens is in line with the findings of Roeder (n.d.), who reported that the DM digestibility of timothy hay was $49.1 \%$. The DM digestibility of alfalfa hay was higher $(50.7 \%)$ compared to the current DM digestibility of T3 diet, but it was lower compared to the T2 $\operatorname{diet}(58.0 \%)$. This suggests that $\mathrm{T} 2$ or $\mathrm{T} 3$ diet containing test forages had better DM digestibility when compared to other common forages that were fed to rabbits. Thus, when combining concentrates with forages, not only can it reduce the feed cost but also lead to use of locally available forages. Moreover, it can reduce dependency on the imported feeds such as timothy, alfalfa and other common forages.

Rabbits fed with T1 diet showed the highest CP digestbility (71.6\%), while those fed with T3 diet showed the lowest (68.5\%). Purwin et al. (2019) found that the CP digestibility of dehydrated alfalfa meal was $71.8 \%$, which is in line with the current study. With increasing demand on animal protein, rabbit is suitable to be reared because of its high ability to convert forage into meat, low cost of production, and high quality protein meat (Amata \& Okorodudu, 2016). Non-significant digestibility in DM, OM, and CP among treatments was found in this study which indicated that the rabbits were able to utilise nutrients from the concentrate, or the combination of concentrate and test forages.

\section{Growth Performance}

Effect of the experimental diets on initial BW, final BW weight, average daily gain, and FCR are presented in Table 3. The average final $\mathrm{BW}$ of rabbits among treatments ranged from $1200 \mathrm{~g}$ to $2130 \mathrm{~g}$. The final BW was not influenced $(p>0.05)$ by the diets. Rabbits fed with T1 diet showed the highest final BW, while rabbits fed with T3 diet showed the lowest. This result might be attributed to the fact that there was no effect of diets on the DM intake by the rabbits. Individual BW of rabbit for marketing is about $1.9-2.0 \mathrm{~kg}$ for White New Zealand or Chinchillia breed; less than this BW is considered to be in low quality. Average final BW of rabbit from T1 diet showed closer weight to the required market weight of rabbit. In the current study, low BW was achieved, and this result may have been caused by the use of mixed breed.

Unlike the final BW, the average total weight gain and the daily weight gain were affected $(p>0.05)$ by the diets. The significantly highest $\mathrm{BW}$ gain and the lowest FCR were obtained with the T1 and T2 diets, whereas the significantly lowest BW gain and the highest FCR were obtained with the T3 diet. This result may have possibly been because of the significant effect of diets on the intake of CP, EE, and NDF. Rabbits fed with T3 diet showed lower BW gain, which might be due to the high fibre content, coarseness, and high DM content of the $B$. decumbens. Iyeghe-Erakpotobor et al. (2006) observed that $25 \%$ levels of soybean cheese waste/maize offal diet 
Table 3

Growth performance of rabbits fed commercial pellet with or without Asystasia gangetica and Brachiaria decumbens

\begin{tabular}{lllll}
\hline Parameter & \multicolumn{3}{c}{ Treatment } & \multirow{2}{*}{$p$-value } \\
\cline { 2 - 4 } & $\mathrm{T} 1$ & $\mathrm{~T} 2$ & $\mathrm{~T} 3$ & \\
\hline Initial weight $(\mathrm{g})$ & $1178 \pm 374$ & $1183 \pm 312$ & $1165 \pm 258$ & 0.997 \\
Final weight $(\mathrm{g})$ & $1745 \pm 416$ & $1650 \pm 216$ & $1320 \pm 159$ & 0.143 \\
Total weight gain $(\mathrm{g})$ & $568^{\mathrm{a}} \pm 61$ & $468^{\mathrm{a}} \pm 132$ & $155^{\mathrm{b}} \pm 106$ & 0.001 \\
Daily weight gain $(\mathrm{g})$ & $11.0^{\mathrm{a}} \pm 1.4$ & $9.0^{\mathrm{a}} \pm 2.7$ & $3.3^{\mathrm{b}} \pm 2.2$ & 0.002 \\
FCR & $12.3^{\mathrm{b}} \pm 1.8$ & $13.9^{\mathrm{b}} \pm 4.4$ & $30.3^{\mathrm{a}} \pm 4.0$ & 0.000 \\
\hline
\end{tabular}

Note. ${ }^{\text {ab }}$ means with different superscripts in a row differ significantly $(p<0.05)$. $\mathrm{T} 1=$ control diet containing $100 \%$ commercial pellet; T2 = half of the control diet plus Asystasia gangetica on ad libitum basis; T3 = half of the control diet plus Brachiaria decumbens on ad libitum basis; FCR = feed conversion ratio

group lost body weight $(-2.08 \mathrm{~g} / \mathrm{d})$ when fed with bracharia hay. In another study, Asuquo (1997) also reported that differences in BW and rate of weight gain of rabbits could be attributed due to the differences in the nutrient composition of the supplied forages. Although B. decumbens is palatable to rabbits, it contains saponins, an antinutrient. However, Faccin et al. (2016) reported that rabbits were not vulnerable to Brachiaria poisoning with concentrations of saponins that are toxic to sheep.

Rabbits fed with $\mathrm{T} 1$ and $\mathrm{T} 2$ diets had similar values of FCR, but their values were lower significantly $(p<0.05)$ than the values of those fed T3 diet. The lower values of FCR implies that the rabbits were able to convert the concentrate and A. gangetica forage more efficiently to meat. The rates of daily weight gain in rabbits fed with $\mathrm{T} 1$ and $\mathrm{T} 2$ diets in this study were in line with daily growth of 5-10 $\mathrm{g}$ in growing rabbits as reported by Iyeghe-Erakpotobor et al. (2001) under tropical conditions.

\section{CONCLUSION}

Overall, the commercial pellet and the diet containing Asyastasia gangetica showed almost similar results. It is recommended for use a diet consisting of half of the concentrate and A. gangetica ad libitum. Not to mention that diet cintaining Brachiaria decumbens instead of $A$. gangetica can also be an alternative, but it is less suggested because lower rate of BW gain may occur. In rural areas where $A$. gangetica and $B$. decumbens forages are available, these could be efficiently utilised for feeding growing rabbits.

\section{ACKNOWLEDGEMENT}

This research work was supported by internal grant ( R/C 19/ A0700/0157A/002/2020/00776 and SGJP/ A07.00/01597A/001/2018/000448) of Universiti Malaysia Kelantan. 


\section{REFERENCES}

Adetula, O. A. (2004). Asystasia gangetica (L.) T. Anderson. Retrieved March 21, 2020, from https://uses.plantnet-project.org/en/Asystasia_ gangetica_(PROTA)

Adigun, O. S., Okeke, E. N., Makinde, O. J., \& Umunna, M. O. (2014). Effect of replacing wheat offal with Asystasia gangetica leaf meal (ALM) on growth performance and haematological parameters of weaner rabbits. Greener Journal of Agricultural Sciences, 4(1), 9-14. doi: 10.15580/ GJAS.2014.1.1211131024

Amata, I. A., \& Okorodudu, E. O. (2016). Comparative evaluation of the growth performance and feed intake of weaned rabbits fed tropical grasses and selected forage leaves. International Journal of Research Studies in Agricultural Sciences, 2(2), 14-18. doi: 10.20431/2455-6224.0202003

Assis, D. D. Y. C. D., de Carvalho, D. G. G. P., Santos, D. E. M., de Oliveira, D. F. A., Araújo, D. M. L. G. M. L. D., Pina, D. D. D. S., . . Rufino, D. L. M. D. A. (2019). Cottonseed cake as a substitute of soybean meal for goat kids. Italian Journal of Animal Science, 18(1), 124-133. doi: 10.1080/1828051X.2018.1490633

Association of Official Analytical Chemists. (2000). Official methods of analysis (17th ed.). Washington D.C., USA: AOAC International.

Asuquo, B. O. (1997). Nutritional potentials of ipomea, centrosema, pueraria, emilia and tridax forages in mixed feeds for weaner rabbits. Nigerian Journal of Animal Production, 24(1), 46-50.

Biobaku, W. O., Bamgbose, A. M., \& Achike, C. U. (2003). Utilisation of different protein sources for growing rabbits. Pertanika Journal of Tropical Agricultural Science, 26(2), 73-77.
Cheeke, P. R. (1987). Rabbit feeding and nutrition. Washington D.C., USA: Academic Press.

Choi, B. R., \& Palmquist, D. L. (1996). High fat diets increase plasma cholecystokinin and pancreatic polypeptide, and decrease plasma insulin and feed intake in lactating cows. The Journal of Nutrition, 126(11), 2913-2919. doi: 10.1093/ jn/126.11.2913

Chuku, E. C., Chuku, O. S., \& Ajuru, M. G. (2018). Studies on the propagation, phytochemical properties, storage, utilization and shelf-life of Asystasia gangetica. Journal of Agriculture and Veterinary Science, 11(8), 63-67. doi: 10.9790/2380-1108016367

Faccin, T., Pupin, R., Leal, P., Santos, A., Lima, S., Ferreira, V., . . Lemos, R. (2016). Evaluation of the toxicity of Brachiaria decumbens in rabbits. Revista Brasileira de Medicina Veterinaria, 38(2), 143-146.

Gopal, T. K., Megha, G., Chamundeeswari, D., \& Reddy, C. U. (2013). Phytochemical and pharmacological studies on whole plant of Asystasia gangetica. Indian Journal of Research in Pharmacy and Biotechnology, 1(3), 365-370.

Iyeghe-Erakpotobor, G. T., Osinowo, O. A., Abdulmalik, M., \& Nwagu, B. I. (2001). Evaluation of growth rates of three breeds of rabbits raised in the northern guinea savanna of Nigeria. Journal of Animal Production Research, $17,78-88$.

Iyeghe-Erakpotobor, G. T., Osuhor, C. U., \& Olugbemi, T. S. (2006). Performance and digestibility of weaner rabbits fed graded levels of soybean cheese waste/maize offal diet and brachiaria grass hay. African Journal of Biotechnology, 5(17), 1579-1583. doi: 10.5897/ AJB06.223 
Khalil. (2016). Crude nutrient and mineral composition of Asystacia gangetica (L.) as a predominant forage species for feeding of goats. Pakistan Journal of Nutrition, 15(9), 867-872. doi: 10.3923/pjn.2016.867.872

Low, S. (2015). Signal grass (Brachiaria decumbens) toxicity in grazing ruminants. Agriculture, 5(4), 971-990. doi: 10.3390/agriculture5040971

Mertens, D. R. (1997). Creating a system for meeting the fiber requirements of dairy cows. Journal of Dairy Science, 80(7), 1463-1481. doi: 10.3168/ jds.S0022-0302(97)76075-2

National Research Council. (1977). Nutrient requirements of rabbits. Washington D.C., USA: NRC.

Owoleke, O. E., Tanimomo, B. K., Adama, T. Z., Akanya, H. O., Alemede, I. C., Abdulrahaman, M., \& Kolawole, V. O. (2016). Feed evaluation and growth performance of rabbits fed diets containing different forages. Vom Journal of Veterinary Science, 11(1), 101-111.

Purwin, C., Gugolek, A., Strychalski, J., \& Fijalkowska, M. (2019). Productvity, nutrient digestibility, nitrogen retention, and meat quality in rabbits fed diets supplemented with Sida hermaphrodita. Animals, 9(11), 901. doi: 10.3390/ani9110901.

Roeder, M. (n.d.). Alfalfa versus timothy hay for rabbits. Retrieved December 27, 2019, from https://www.purinamills.com/rabbit-food/ education/detail/alfalfa-versus-timothy-hayfor-rabbits
Safwat, A. M., Sarmiento-Franco, L., Santos-Ricalde, R. H., \& Nieves, D. (2014). Determination of tropical forage preferences using two offering methods in rabbits. Asian-Australasian Journal of Animal Sciences, 27(4), 524-529. doi: 10.5713/ajas.2013.13163

Silva, C. S., Montagner, D. B., Euclides, V. P. B., Queiroz, C. D. A., \& Andrade, R. A. S. (2016). Steer performance on deferred pastures of Brachiaria brizantha and Brachiaria decumbens. Ciência Rural, 46(11), 1998-2004. doi: 10.1590/0103-8478cr20151525

Sobayo, R. A., Adeyemi O. A., Sodipe, O. G., Oso, A. O., Fafiolu, A. O., Ogunade, I. M., ... Omoniyi, L. A. (2012). Growth response of broiler birds fed Asystasia gangetica leaf meal in hot humid environment. Journal of Agricultural Science and Environment, 12(1), 53-59.

Suhaimi D., Sharif, S., Normah, M. A., Nadia, M. N., \& Syahidah, H. W. (2017). Estimating relative feed value of local Brachiaria decumbens. Malaysian Journal of Veterinary Research, 8(2), 78-82.

Van Soest, P. J., Robertson, J. B., \& Lewis, B. A. (1991). Methods for dietary fiber, neutral detergent fiber, and nonstarch polysaccharides in relation to animal nutrition. Journal of Dairy Science, 74(10), 3583-3597. doi: 10.3168/jds. S0022-0302(91)78551-2 
